\title{
Developmental Aspects of Regional Airports in the Czech Republic
}

\author{
KANIA David ${ }^{1, a^{*}}$ \\ ${ }^{1}$ Partyzánské náměstí 1738/2, 702 00, Ostrava, Czech Republic \\ adavid.kania@kania-ostrava.cz
}

\begin{abstract}
Keywords: airport, international airport, regional airport, developmental aspects, IATA, RWY
\end{abstract}
\begin{abstract}
The aim of the article is the comparison of development aspects of regional airports of the Czech republic. Only international airports have been chosen, specifically airports given the IATA code (IATA - International Air Transport Association). The selection of airports was influenced by the following factors - the condition of the air transport and the length of the take-off and landing tracks. After mutual comparison, all international airports with regular and irregular trade transport were chosen. The concerned airports are: Brno - Tuřany Airport (BRQ), Leoš Janáček Airport Ostrava (OSR), Pardubice Airport (PED) a Karlovy Vary Airport (KLV). Václav Havel Airport (PRG), which, as the capital airport, would considerably influence the assesment of the observed values, was deliberately not included in the listing. The individual airports are assessed due to the influence of the parameters of the take-off and landing tracks, namely the length of the tracks (the length of the track needed for airplane take-off under standard conditions, i.e. not including the influence of the airport altitude, airport reference temperature and the longitudinal inclination of RWY) and the parameters of the radionavigation and lighting equipment. Other followed aspects are the population number of the given city (or cities placed near the airport), location towards the city center and its transportation connection. Another observed aspect is the influence of competing airports from near abroad on the development of the airport. The intention is to confirm or disprove the idea that the best equipped and situated airport (the airport with the largest potential), should show the best performance, i.e. the number of dispatched passengers and the amount of transported cargo load.
\end{abstract}

\section{Introduction}

This paper aims to compare the developmental aspects of regional airports in the Czech Republic. Only international airports were included in the selection, namely airports with an IATA code (IATA - International Air Transport Association). The following factors affected the selection of airports: air transport volume and the runway length. All public international airports with scheduled and non-scheduled commercial traffic have been included in the selection, these airports being The Brno - Tuřany Airport (BRQ), Leoš Janáček Airport Ostrava (OSR), Pardubice Airport (PED) and Karlovy Vary Airport (KLV). The list intentionally excludes the Vaclav Havel Airport (PRG), which, being the airport of the capital city, would have excessive impact on the evaluation of the monitored statistical data. In terms of individual airports, the author evaluates the impact of runway parameters, reference field length and the parameters of radio navigation and lighting equipment. Other monitored aspects include the population of the respective cities (or cities where the airport is located), the airport's location relative to the city centre and its transport connection. The last monitored aspect is the impact of competing foreign airports from across the border on the regional airport's development. The aim is to prove or disprove the idea that the airport with best equipment and location (airport with the greatest potential) should exhibit the best performance in terms of the number of passengers throughput, number of movements and the cargo throughput. 


\section{Definitions}

Airport (Aerodrome) - a defined area on land or water (including any buildings, installations and equipment) intended to be used either wholly or in part for the arrival, departure and surface movement of aircraft. [1] An airport is a territorially defined and appropriately landscaped area including aeronautical buildings and airport facilities permanently intended for take-offs and landings of aircraft and the associated aircraft movements. [2] RWY/Runway - defined rectangular area on a land aerodrome prepared for the landing and takeoff of aircraft. [1] Aeroplane reference field length - the minimum field length required for take-off at maximum certificated take-off mass, sea level, standard atmospheric conditions, still air and zero runway slope, as shown in the appropriate aeroplane flight manual prescribed by the Civil Aviation Authority or other certificating authority of another state or equivalent data from the aeroplane manufacturer. [1] IFR - Instrument flight rules [3]

\section{Regional Airports Of The Czech Republic}

Brno-Tuřany Airport. City: Brno; Population: 380 000; Region: South Moravia; IATA Code: BRQ, ICAO code: LKTB; RWY: 2650x60 m; transport connection: the city and the airport are connected through a regular bus service; railway connection: no direct railway connection, indirect connection through the station in the city (bus line ends at the station); road connection: D1 - the core motorway of the Czech Republic - is located in the vicinity (north) of the airport, with D2 motorway connecting to it south of the airport (direction south to Slovakia); location relative to the city centre: $7.5 \mathrm{~km} \mathrm{SE}$; competing airport: Vienna/Wien (VIE), $155 \mathrm{~km}, 110$ minutes' drive (R52E461-A5-A24-A4) and Bratislava (BTS), 145 km, 90 minutes' drive (D2)

Leoš Janáček Airport Ostrava. City: Ostrava; Population: 295,000 (Ostrava agglomeration 560,000); Region: Moravian-Silesian; IATA Code: OSR; ICAO code: LKMT; RWY: 3500x63 m; transport connection: the city and the airport are connected through a regular bus service; railway connection: no direct railway connection, railway connection is currently under construction, scheduled to commence operation in 2015; road connection: D1 - the core motorway of the Czech Republic - is located $13 \mathrm{~km}$ north of the airport, with R48 high-speed road located $6 \mathrm{~km}$ south of the airport (direction to Frýdek-Místek); location relative to the city centre: $24 \mathrm{~km} \mathrm{SW}$; competing airport: Katowice (KTW), 140 km, 95 minutes' drive (D1-A1) and Cracow/Kraków (KRK), 185 km, 120 minutes' drive (D1-A1-A4)

Pardubice Airport. City: Pardubice; Population: 89,500 (182,500 including the population of Hradec Králové); Region: Pardubice; IATA Code: PED; ICAO code: LKPD; RWY: 2500x75 m; transport connection: the city and the airport are connected through a regular bus service; railway connection: only through the station on the main railway line of the Czech Republic; road connection: only local road network, high-speed road linking the city with Hradec Králové and provisional end of the D11 motorway (Prague - Hradec Králové) located north of the city; location relative to the city centre: $3 \mathrm{~km} \mathrm{SW}$; competing airport: Wrocław (WRO), $195 \mathrm{~km}, 170$ minutes' drive (E67)

Karlovy Vary Airport. City: Karlovy Vary; Population: 50 000; Region: Karlovy Vary; IATA Code: KLV; ICAO code: LKKV; RWY: 2150x30 m; the city and the airport are connected through a regular bus service; railway connection: no direct connection, only indirect connection through the train station in the city (however somewhat complicated); road access: I/6 road (Praha-Karlovy Vary) is located north of the airport, conversion to a high-speed road is being planned, the city is well connected by high-speed roads going westwards (Cheb, border with Germany) and to the north-west (however, the high-speed road soon connects to the regular road network, location relative to the city centre: $3,8 \mathrm{~km} \mathrm{SSW}$; competing airport: Dresden (DRS), $165 \mathrm{~km}, 125$ minutes' drive (B95-A4) and Nuremberg/Nürnberg (NUE) 216 km / 135 minutes' drive (R6-B299-A93-A3A6) 
The list of competing airports only includes international airports. The biggest natural competitor for the regional airports of the Czech Republic is the Vaclav Havel Airport (PRG) in Prague as the airport of the capital. In terms of competition, its impact on the monitored Czech regional airports is identical.

Table 1 - Basic technical parameters of regional airports in the Czech Republic

\begin{tabular}{|c|c|c|c|c|c|c|c|}
\hline \multirow[b]{2}{*}{ airport } & \multirow{2}{*}{$\begin{array}{l}\text { IATA } \\
\text { code }\end{array}$} & \multirow{2}{*}{$\begin{array}{l}\text { ICAO } \\
\text { code }\end{array}$} & \multicolumn{2}{|l|}{ RWY } & \multirow{2}{*}{$\begin{array}{l}\text { Reference } \\
\text { field } \\
\text { length }\end{array}$} & \multirow[b]{2}{*}{$\mathrm{PCN}$} & \multirow[b]{2}{*}{ IFR } \\
\hline & & & $\begin{array}{l}\text { Length } \\
{[\mathrm{m}]}\end{array}$ & $\begin{array}{l}\begin{array}{l}\text { Width } \\
{[\mathrm{m}]}\end{array} \\
\end{array}$ & & & \\
\hline Brno-Tuřany Airport & BRQ & LKTB & 2,650 & 60 & $2,242 \mathrm{~m}$ & $48 / \mathrm{R} / \mathrm{A} / \mathrm{X} / \mathrm{T}$ & CAT I \\
\hline Leoš Janáček Airport Ostrava & OSR & LKMT & 3,500 & 63 & $2,914 \mathrm{~m}$ & $50 / \mathrm{R} / \mathrm{B} / \mathrm{W} / \mathrm{T}$ & CAT II \\
\hline Pardubice Airport & PED & LKPD & 2,500 & 75 & $2,151 \mathrm{~m}$ & $47 / \mathrm{R} / \mathrm{B} / \mathrm{W} / \mathrm{T}$ & IFR \\
\hline Karlovy Vary Airport & KLV & LKKV & 2,150 & 30 & $1,692 \mathrm{~m}$ & $54 / \mathrm{F} / \mathrm{A} / \mathrm{X} / \mathrm{T}$ & CAT I \\
\hline
\end{tabular}

\section{Evaluation In Terms Of Technical Parameters, Regional Demography, Transport Infrastructure And Competition From Airports From Across The Border}

Individual airports were evaluated in terms of the parameters of the runway, reference field length (field length required for take-off under standard conditions, i.e. excluding the impact of aerodrome elevation, aerodrome reference temperature and longitudinal runway slope) and parameters of radio navigation and lighting equipment. Each monitored parameter of the relevant aerodrome was assigned a score of 1 to 4 ( 1 being best, 4 being worst).

Other monitored aspects include the population of the relevant city, location relevant to the city centre and its transport connections and the impact of competing airports from across the border on the development of the regional airport.

Brno-Tuřany Airport. Brno's population was the largest of the monitored cities; however, the score is 2 as the population of the Ostrava agglomeration is larger. In terms of transport connection, Brno is by far the best, both in terms of national motorways, and also in the combination with the connection to the city centre. Brno is exposed to the highest level of competition, as it competes with two major airports of two capitals: Vienna (21,999,926 passengers in 2013) and Bratislava (1,416,010 passengers in 2012).

Leoš Janáček Airport Ostrava. The Ostrava agglomeration has the largest population. It has excellent transport connection thanks to the national motorway; however, connection to the city centre is the worst of all monitored airports. In terms of the combined evaluation of the transport connection, Ostrava's score was 2. The Ostrava airport is exposed to competition from two fastgrowing and easily accessible airports in Poland: Katowice (2,544,198 passengers in 2013) and Krakow (3,647,616 passengers in 2013).

Pardubice Airport. Pardubice (including the inhabitants of Hradec Králové) has the third largest population of the monitored regions. Transport connection in terms of the national motorways goes only one way to D11, connection to the city centre through local road network is excellent. In terms of the combined evaluation of transport connection, Pardubice's score was 3 . The Pardubice airport only competes with one poorly accessible airport in Poland: Wroclaw (1,920,179 passengers in 2013).

Karlovy Vary Airport. Karlovy Vary is the smallest regional city with an international airport in the Czech Republic. Transport connection in terms of the national motorways is the worst of all the monitored airports; the connection to the city centre through local road network is sufficient. Karlovy Vary airport competes with two German airports: Dresden (1,754,139 passengers in 2013) and Nuremberg $(3,309,629$ passengers in 2013). 


\section{Overall Evaluation Of Developmental Aspects}

The above data from all six monitored developmental aspects was used to prepare an overall evaluation table showing the potential of each airport. All aspects have statistically equal weight, i.e. $20 \%$ for each monitored aspect.

Table 2 - Overall evaluation of the developmental aspects of the airports in the Czech Republic

\begin{tabular}{|l|l|l|l|l|l|l|l|l|}
\hline $\begin{array}{l}\text { IATA } \\
\text { code }\end{array}$ & RWY & $\begin{array}{l}\text { Reference field } \\
\text { length }\end{array}$ & IFR & Population & $\begin{array}{l}\text { Transport } \\
\text { connection }\end{array}$ & $\begin{array}{l}\text { Competing } \\
\text { airport }\end{array}$ & $\begin{array}{l}\text { Total } \\
\text { score }\end{array}$ & $\begin{array}{l}\text { Ranking of } \\
\text { airports by } \\
\text { development } \\
\text { potential }\end{array}$ \\
\hline BRQ & 2 & 2 & 2 & 2 & 1 & 4 & 13 & 2 \\
\hline OSR & 1 & 1 & 1 & 1 & 2 & 3 & 9 & 1 \\
\hline PED & 3 & 3 & 4 & 3 & 3 & 1 & 17 & 3 \\
\hline KLV & 4 & 4 & 2 & 4 & 4 & 2 & 20 & 4 \\
\hline
\end{tabular}

Performance Evaluation Of Regional Airports In the Czech Republic (2009 - 2013)

Performance evaluation of individual airports in the monitored period $(2009-2013)$ examines the parameters of passenger throughput, total aircraft movements and cargo throughput. All data are available on the official website of each airport. [5], [6], [7], [8]

Table 3 - Cumulative evaluation of the performance of individual airports $(2009-2013)$

\begin{tabular}{|l|l|l|l|l|l|}
\hline airport & IATA code & ICAO code & passengers & movements & cargo (t) \\
\hline Brno-Tuřany Airport & BRQ & LKTB & $2,393,382$ & 140,065 & 27,533 \\
\hline Leoš Janáček Airport Ostrava & OSR & LKMT & $1,408,226$ & 75,090 & 10,111 \\
\hline Pardubice Airport & PED & LKPD & 485,728 & 9,259 & 1,646 \\
\hline Karlovy Vary Airport & KLV & LKKV & 429,943 & 8,419 & 233 \\
\hline
\end{tabular}

Table 1 - Basic technical parameters of regional airports in the Czech Republic clearly shows that the Leoš Janáček Airport Ostrava has a runway with the best parameters and equipment of all regional airports in the Czech Republic, the difference being quite significant compared to other airports that have shorter or even narrower runways and worse radio navigation and lighting equipment. In terms of technical parameters, the Ostrava airport has an excellent position. The reference field length (field length required for take-off under standard conditions, i.e. excluding the impact of aerodrome elevation, aerodrome reference temperature and longitudinal runway slope) is relatively high, allowing the operation of almost all aircraft with no restrictions in terms of takeoff weight, or with minor restrictions for the largest aircraft types (A 340, B 777 etc.).

However, the results shown in Table 3 - Cumulative evaluation of the performance of individual airports (2009 - 2013) show that the most successful regional airport in Czech Republic is the BrnoTuřany Airport which, compared to the airport with the largest development potential (Leoš Janáček Airport Ostrava) reported within the five-year evaluation period a higher number of passengers (by 985,156 passengers, i.e. $70 \%$ more passengers), a higher number of movements (by 64,975 , i.e. $86 \%$ more aircraft movements) and higher cargo throughput (by 17,422 tons, i.e. 172\% more cargo throughput). In addition, the Brno-Turany Airport is exposed to the highest level of competition, because it competes with two major airports of two capitals - Vienna and Bratislava - which have great transport connection to Brno.

The results of the performance evaluation of the Pardubice Airport and Karlovy Vary Airport correspond to their levels of development potential. Cargo throughput of the Karlovy Vary Airport is lower, which is due to the fact that the airport started handling cargo only in 2011. 


\section{Conclusion}

The aim was to prove or disprove the idea that the airport with best equipment and location (airport with the greatest potential) should exhibit the best performance, i.e., number of passenger throughput, number of movements and the amount of cargo throughput. This idea has been disproved as the most successful airport in the Czech Republic is Brno-Turrany Airport which, compared to the airport with the largest development potential (Leoš Janáček Airport Ostrava), reported significantly better performance in terms of the monitored parameters within the five-year evaluation period. The results of the performance evaluation of the Pardubice Airport and Karlovy Vary Airport correspond to their levels of development potential.

\section{References}

[1] Ministry of Transport of the Czech Republic, the author: The Civil Aviation Authority, Aviation Regulation, Airport, L14, published under the reference number: 641/2009-220-SP/4.

[2] Act no. 49/1997 Sb. of 6 March 1997 on civil aviation and amending Act No. 455/1991 Sb. on licensed trades (Licensed Trades Act), as amended

[3] Ministry of Transport of the Czech Republic, the author: The Civil Aviation Authority, Aviation Regulation, L6, Operation of Aircraft, Part I, published under the reference number: 35/2012-220$\mathrm{SP} / 2$.

[4] Ministry of Transport of the Czech Republic, the author: The Civil Aviation Authority, Aviation Regulation, L6, Operation of Aircraft, Part II, published under the reference number: 61/2010-220$\mathrm{SP} / 1$.

[5] The official website of Brno - Tuřany Airport, www.brno-airport.cz

[6] The official website of Leoš Janáček Airport Ostrava, www.airport-ostrava.cz

[7] The official website of Pardubice Airport, www.airport-pardubice.cz

[8] The official website of Karlovy Vary Airport, www.airport-k-vary.cz 